\title{
Rear-Arc Tectonic Setting of Neoproterozoic Calc-Alkaline Picrite- Basalt-Basatic Andesite Magmas in Jiangnan Orogen of South China
}

\author{
JIAWEI ZHANG ${ }^{1}$, MINGYANG LIAO ${ }^{2}$ \\ ${ }^{1}$ Guizhou Geological Survey, Bureau of Geology and Mineral \\ Exploration and Development of Guizhou Province, Guiyang \\ 550081, China \\ ${ }^{2}$ School of Mining Engineering, Guizhou Institute of Technology, \\ Guiyang 550003, China
}

Chemical composition of basalt is a critical indicator for the primary magma composition, thermal state of the mantle and tectonic setting discrimination. The Jiangnan Orogen in South China is commonly regarded as a Neoproterozoic orogenic belt, but the tectonic setting of the widespread Middle Tonian basaltic rocks in this orogen are still disputed for different opinions. In this study, detailed field investigation and petrogeochemistry study have been carried out of the Middle Tonian Fanjingshan basaltic rocks in the southwestern Jiangnan Orogen. Furthermore, a database of 131 whole rock geochemical and $33 \mathrm{Sr}-\mathrm{Nd}$ isotopes data of co-magmatic basaltic rocks in the whole Jiangnan Orogen are also compiled in order to decipher the magma evolution, calculate the primary magma composition, estimate the mantle potential temperature (Tp) and discriminate the tectonic setting. Both calc-alkaline picrites, basalts and basaltic andesites (Type A magmas) and tholeiitic basalts (Type B magmas) with distinct geochemical characteristics are identified as interbedded layers accompany with the Neoproterozoic basement sequences (Fanjingshan Group and its equivalents). The calculated primary magma composition of the Type A magmas belong to the picrite. Slab-derived fluids play an important role in magma genesis and the estimated average Tp of these magmas $\left(1451{ }^{\circ} \mathrm{C}\right)$ is consistent with a mantle wedge due to rapid slab roll-back process, but much lower (by $119{ }^{\circ} \mathrm{C}$ ) than that produced by a hot mantle plume. Considering its continental arc signatures, together with the existence of the coeval tholeiitic magmas with BABB-like feature (Type B magmas) and the bidirectional sources for the contemporaneous sedimentary rocks in Jiangnan Orogen, we suggest that the Type A magmas were derived from the continental rear-arc setting at the margin of the Yangtze block. We further propose that there was a complex subduction-related arcbasin system had developed on the periphery of Rodinia supercontinent during Middle Tonian. 